https://www.sworldjournal.com/index.php/swj/article/view/swj06-02-036 DOI: 10.30888/2663-5712.2020-06-02-036

УДК 631.42:631.434

SOIL IS A THERMODYNAMIC SYSTEM AND SUBSTANTIATION OF ITS HOMEOSTASIS CONCEPT

ГРУНТ ЯК ТЕРМОДИНАМІЧНА СИСТЕМА ТА ОБГРУНТУВАННЯ ПОНЯТТЯ ЙОГО ГОМЕОСТАЗУ

Kolomiiets S.S. / Коломісць C.C. c.a.s. / א.c.-2.H. ORCID: 0000-0002-4329-4382

Bilobrova A.S. / Білоброва A.C. postgraduate / acnipaнm ORCID: 0000-0002-0540-9492

Institute of Water Problems and Land Reclamation of NAAS of Ukraine, Kyiv, Vasylkivska, 37, 03022 Інститут водних проблем і меліорачії НААН Украӥни, Київ, Васильківська, 37, 03022

\begin{abstract}
Анотація. Метою публікації є розкриття внутрішніх процесів, щзо відбуваються у трунті при взаємодії з циклічно мінливими зовнішніми кліматичними факторами та обтрунтування поняття гомеостазу трунту. Використані методи синергетики $i$ термодинаміки, експериментальні дослідження. Експериментально встановлено виникнення автоколивального процесу динаміки капілярного потенціалу під дією зміни температури, атмосферного тиску або вологості. В основі иъьго явища $\epsilon$ затиснення рідинними мембранами у розширеннях порового простору повітря, яке реагує на мінливість зовнішніх термодинамічних параметрів зміною свого об'єму і газового тиску, як мембранна помпа. Це породжує в довкіллі затиснутого повітря низку відиентрових локальних процесів: перерозподілу вологи з конвективним переносом речовини, зміною $р Н$, порушення фазової рівноваги, селекцію сполук, чутливих до кислотності, зонування у просторі та їх перевідкладення. Це забезпечує нерівномірну цементацію дисперсних часток та визначає зародки окремостей, на які розпадається трунт при обробітках. Інтенсивність субординачійних процесів визначає рівень перетворення (дисипачї) зовнішнього потоку енергї (сония). У загальному випадку ияя інтенсивність визначається: конструкцією системи (структурою порового простору); наявністю вологи, як робочого тіла, від вмісту якої залежить ККД термодинамічної системи трунту та інтенсивністю коливань зовнімніх термодинамічних параметрів. 3 позицій синергетики трунт визначений як мікроградієнтна дисипативна система потокового типу. Гомеостаз трунту визначений як сукупність субординаційних енерговитратних процесів, які обумовлюють певний рівень перетворення (дисипаціï) потоку сонячної енергії та забезпечують відтворення структурної організачії $i$ основних властивостей, а також реалізують продуктивну $і$ екологічну функиіі трунту. Поняття гомеостазу трунтів є незамінним для оиінки еволючійних змін їх властивостей за сучасних глобальних кліматичних змін.
\end{abstract}

Ключові слова: трунт, термодинамічна система, синергетика, гетерогенність, гомеостатичні прочеси, затиснення повітря, структура порового простору, гомеостаз трунту

\title{
Постановка проблеми.
}

Сучасний стан невпинної втрати у всьому світі родючості грунтів [4] вимагає пошуку нових шляхів вирішення цієї світової екологічної проблеми. Сучасні глобальні кліматичні зміни лише загострюють проблему збереження родючості грунтів і значною мірою пов'язані 3 цим глобальним процесом деградації грунтового покриву. 
Вадою поглядів домінуючого нині генетичного грунтознавства, що розглядає довготривалий процес утворення грунтів, властивості яких вважають сталими в масштабі реального часу, є відсутність параметричних моделей їхньої динаміки. Через що нині відсутня теорія агрогенної еволюції грунтів [1]. I саме цей факт не дозволяє ефективно управляти їх властивостями, адже еволюційні зміни властивостей грунтів, що відбуваються протягом років i десятирічь, фіксуються у всіх агрогенних грунтах, тобто в масштабі реального часу.

В минулому сторіччі жваво йшла дискусія стосовно понять «грунтпам'ять» та «грунт-момент» $[11,18]$. Однак, «грунт-момент» за тих позицій розглядають як сукупність динамічних лабільних властивостей, що $\epsilon$ результатом сукупності факторів i процесів під час спостережень, або у наближених до них у часі. Але при цьому розглядають характерний час утворення i стирання певних властивостей оперуючи термінами у роки та десятиріччя [18]. Якщо для грунту це має значення, в аспекті «грунт-пам'ять», то для відображення термодинамічної взаємодії грунту 3 довкіллям такий термін динаміки стану непридатний. Адже у кожний момент у кожній точці середовища грунту відбувається вплив зовнішніх термодинамічних факторів на динаміку стану грунту, яку рослини, як адаптивні системи, успішно використовують у продукційному процесі. I одним із завдань цієї публікації $\epsilon$ встановлення механізму такої дії.

В літературі декларується, що грунт - це відкрита (термодинамічна) система, що обмінюється 3 довкіллям речовиною, енергією та інформацією $[16,21]$. На обміні речовиною 3 довкіллям базується домінуюча нині у землеробстві система відтворення родючості грунту, відповідно до закону повернення біогенних елементів. Однак без врахування двох інших складових обміну, ця система $є$ недостатньо ефективною, через що у всьому світі спостерігається процес деградації грунтів 3 подальшою втратою їхньої родючості [4].

За канонами фізики робота системи є добутком фактора ємкості та фактора інтенсивності. I саме неврахування фактора інтенсивності (кліматичних чинників) у продукційному процесі рослин призводить до суттєвих коливань продуктивності сільськогосподарських культур 3 року в рік за незначних коливань вмісту у грунті біогенних елементів, тобто фактора ємкості. Отже обмін грунту з довкіллям енергією впливає на доступність 3 грунту живлення для рослин у векторі грунт-рослина-атмосфера. Фактично вивчення енергетичної взаємодії грунту 3 довкіллям почалося 3 формування $€$. Букінгемом, ще на початку минулого сторіччя (1907р.) поняття потенціалу вологи [24] та винайдення В.Г. Корнєвим у 20-х роках приладу для вимірювання сили утримання вологи ненасиченим грунтом - тензіометра [9]. У подальшому В.Р. Волобуєвим здійснені спроби оцінки енергетики процесів грунтоутворення [2] та спроби встановлення взаємозв’язку між класичними термодинамічними функціями - потенціалом Гіббса i ентропією та мінералогічним складом і фільтраційною здатністю грунтів [3]. Однак засобами класичної рівноважної термодинаміки неможливо вивчати перманентно 
нерівноважну термодинамічну систему грунту, яка постійно взаємодіє 3 різноперіодичними циклічними термодинамічними факторами зовнішнього середовища. Для дослідження термодинамічно нерівноважних грунтових процесів доцільно застосовувати інструментарій синергетики - порівняно молодої наукової дисципліни, що була створена у 70-80 роках минулого сторіччя, предметом якої $є$ термодинаміка нерівноважних процесів i теорія самоорганізації складних систем[15, 23$]$.

Застосування поняття потенціалу вологи (капілярного потенціалу) у ненасичених водою грунтах дозволяє будувати градієнтну параметричну модель вологообміну у грунті. Саме на капілярний (матричний) потенціал вологи здійснюють вплив зовнішні циклічні збурення термодинамічних параметрів довкілля, тим самим впливаючи на доступність живлення для рослин. Адже рослини у власному продукційному процесі керуються правилом мінімізації витрат власної енергії на споживання. Через вологу, як основний агент живлення, рослинами споживаються всі водорозчинні сполуки i здійснюється більшість біохімічних перетворень речовини у грунті, тому доступність для рослин вологи відповідно до значень потенціалу, може бути ототожнена 3 доступністю складових живлення. Адже в трифазній гетерогенній системі ненасиченого водою грунту величина термодинамічного потенціалу може бути визначена у будь-якій фазі, а найпростіше і найдоступніше його визначити саме у фазі рідини.

У взаємодії грунту з довкіллям слід звернути увагу на пріоритетну дію добових коливань зовнішніх термодинамічних параметрів, зокрема температури, на потенціал вологи у грунті. Саме добовий цикл забезпечує найвищу, порівняно 3 циклічністю вищих порядків, швидкість реакції потенціалу грунту на зовнішні збурення. Адже фізіологічний цикл споживання у рослин теж має добовий цикл. I, найвірогідніше, рослини, як адаптивні системи, йшли шляхом пристосування до добового циклу динаміки потенціалу у первинно косному (мінеральному) грунті.

Обмін грунту 3 довкіллям інформацією практично не вивчений, це своєрідна terra incognita. Хоч на інформаційний характер грунтових процесів вчені звертали увагу ще у минулому сторіччі [13]. Нині доведено, що у грунті циркулює інформація не у класичному варіанті, одиницею якої є біт, а так звана зв’язана інформація у вигляді грунтових режимів [20, 23], яка має властивість накопичуватись в системі, зокрема у грунті у формі негентропії, тобто від’ємної ентропії. Стійкість системи до зовнішніх збурень керована законом накопичення інформації (негентропії) - чим більше в системі накопичено інформації, тим вона $\epsilon$ стійкішою до зовнішніх збурень. Однак поки достеменно не встановлено механізм накопичення інформації у грунті. Зокрема $\epsilon$ підстави вважати інформаційними індикаторами кількості негентропії у грунті розвиток структури та вміст гумусу. Тому сучасні процеси дегуміфікації та знеструктурення слід розглядати як втрату грунтом інформації з відповідним зниженням його стійкості до зовнішніх факторів. Грунт це потужний інформаційний медіатор і важливим аспектом інформаційної взаємодії грунту 3 довкіллям є трансформація зовнішнього потоку (кліматичної) інформації та 
перетворення iï у грунтові режими, які безпосередньо впливають на продукційний процес рослин, формуючи в рослинницькій продукції певне інформаційне навантаження. Це інформаційне навантаження на вирощену продукцію виступає вже як якість цієї продукції, що у подальшому передається трофічними ланцюгами, у т.ч. і до людини. У найближчому майбутньому слід очікувати, що ефективність землеробства (рослинництва) будуть оцінювати не рівнем врожайності, а інформаційною якістю вирощеної продукції, що виводить на передові позиції органічне землеробство.

Отже, слід констатувати, що створення теорії агрогенної еволюції грунтів та теорії управління грунтовою родючістю неможливе без розгляду обміну грунту з довкіллям не тільки речовиною, але й енергією та інформацією.

Метою цієї публікації $є$ представлення альтернативного погляду на грунт як термодинамічну систему, що обмінюється речовиною, енергією та інформацією 3 довкіллям, а також встановлення внутрішніх енерговитратних процесів, що виникають у грунті при взаємодії 3 циклічними зовнішніми збуреннями, які забезпечують його гомеостаз, тобто відтворення структурної організації і основних властивостей.

Основними методами $є$ системний аналіз i синтез на основі ідей системної філософії, а також експериментальні дослідження грунту із залученням термодинамічних гідрофізичних методів.

\section{Результати та їх обговорення.}

Першочерговим завданням було встановлення дії зовнішніх кліматичних факторів: температури $\left(\mathrm{T}^{\circ} \mathrm{C}\right)$, атмосферного тиску $\left(\mathrm{P}_{\text {атм}}\right)$ та вологи $(\theta, \%)$ на енергетичний стан гетерогенної системи грунту. Температура $\mathrm{i}$ волога розповсюджуються у грунтовому середовищі у вигляді теплових хвиль і хвиль зволоження від поверхні грунту, тобто вони мають градієнтну структуру, на відміну від атмосферного тиску, який діє одночасно у всьому об'єму грунту.

Фундаментальними властивостями грунту $\epsilon$ його гетерогенність та гістерезисність. I саме на ці властивості впливають зовнішні циклічні термодинамічні фактори. Найчутливішою до них виявилась поверхня розділу рідина-повітря, яка визначає поверхневу енергію системи ненасиченого грунту через радіуси кривизни менісків порового розчину і загальну іiі площу. Площа цієї поверхні розділу функціонально пов'язана із вологонасиченням грунту i визначається кривою водоутримувальної здатності $\theta=f(P)$ [15].

Однак ця залежність ускладнена гістерезисністю, тобто неоднозначністю взаємозв'язку капілярного потенціалу 3 вологонасиченням грунту. I якщо більшість дослідників свідомо уникають цієї проблеми, вона відноситься до найважливіших для грунту, як пророче звертав увагу на гістерезис відомий вчений у області гідрології грунтів О.О. Роде [17].

Капілярний гістерезис обумовлений нерегулярністю перетину уявних капілярів, якому відповідає модель чоткового капіляра Жамена. Через що в розширеннях порового простору, за зміни десорбції, на сорбцію рідинними мембранами затискається бульбашка повітря [10], яка знижує загальне вологонасичення грунту, за однакових із процесом десорбції значень капілярного потенціалу. Експериментально доведено, що величина гістерезису, 
тобто різниці вологонасичення грунту за однакових значень капілярного потенціалу, може сягати десятків відсотків від об’єму грунту. Відділена від грунтової атмосфери рідинними мембранами бульбашка повітря починає реагувати на зміну зовнішніх термодинамічних параметрів - температури, атмосферного тиску та вологонасичення грунту. Тобто така бульбашка відіграє роль мембранної помпи у грунті. I синергізм розподілених у об’ємі грунту мікромембранних помп призводить до зміни термодинамічного стану потенціалу грунту на рівні макропараметра системи.

Якщо пов’язати поверхневу енергію системи ненасиченого грунту 3 площею поверхні розділу рідина-повітря, то з'ясовується, що до площі поверхні розділу на контакті 3 грунтовою атмосферою, яку можна назвати екстрагетерогенністю (зовнішньою), додається ще й внутрішня площа поверхні бульбашок затиснутого повітря, яку можна назвати інтрагетерогенністю (внутрішньою). Тобто гістерезис збільшує поверхневу енергію ненасиченого грунту на величину інтрагетерогенності. Цей факт $\epsilon$ надзвичайно важливим, адже при цьому грунт стає енергонадлишковим. I дійсно, за однакового вологонасичення капілярний потенціал системи збільшується і волога стає доступнішою для рослин.

Для детальнішого відображення динаміки енергетичного стану грунту в умовах гістерезису була розроблена синтетична фізична модель порового простору у вигляді гофрованого еквівалентного капіляра [8]. Ця модель поєднує модель чоткового капіляра Жамена, що враховує нерегулярність перетину капілярів, та модель еквівалентного капіляра А.В. Ликова [10], кривизна якого враховує інтегрально об'єм усіх пор різного розміру. Згідно моделі гофрованого еквівалентного капіляра в групі пор, де виконується умова рівноваги - рівності радіусів кривизни менісків рідинної мембрани із зовні i всередині $r_{a}=r_{\text {зп }}$, затиснута бульбашка повітря знаходиться в рівноважному стані. У грунті відповідно до прийнятої моделі, існує група пор, для якої умова рівноваги виглядає як:

$$
r_{\max } \geq r_{a} \geq r_{\min }
$$

де $r_{\max }$ - максимальний радіус кривизни вписаної кулі у розширенні уявного капіляра;

$r_{a}-$ радіус кривизни узагальнюючого меніску на контакті з атмосферою (екстрагетерогенності);

$r_{\min }$ - радіус кривизни вписаної кулі у найвужчому місці (шийці) пори.

Отже у будь-якому ненасиченому грунті затиснуте повітря знаходиться в групі пор певного розміру в рівноважному стані i саме воно становить сумарний об’єм мікропомп, які реагують на зміну зовнішніх термодинамічних параметрів - температури, атмосферного тиску та вологонасичення. Синергізм взаємодії таких мікропомп, що розподілені в об'ємі грунтового середовища, викликає динаміку потенціалу вологи у всьому об'ємі грунту. В цьому полягає сутність термодинамічної взаємодії грунту з циклічно мінливими факторами 
зовнішнього середовища.

Було експериментально доведено вплив теплового імпульсу та зовнішнього газового тиску на капілярний потенціал грунту. Приміром нагрівання ізольованого зразка лесовидного грунту сталого вологонасичення ( $\theta=$ const) призводило до виникнення автоколивального процесу динаміки

капілярного потенціалу 3 амплітудою 21,5 кПа. Це свідчило про внутрішньопоровий перерозподіл вологи із зростанням поверхневої енергії грунту за рахунок інтрагетерогенності. Відповідно до моделі гофрованого еквівалентного капіляра з початком нагрівання за рахунок збільшення об'єму бульбашки повітря 3 тіла пори витискається поровий розчин. Синергізм взаємодії бульбашок призводить до ефекту зволоження грунту і починається лавиноподібне закриття рідинними мембранами пор все більшого радіусу у напрямку $\mathrm{r}_{\mathrm{a}} \rightarrow \infty$, тобто до пласкої поверхні, що характеризує повне насичення

грунту водою. Цьому також сприяє зниження капілярного натягу рідини через зростання температури [10]. I чим швидше йде нагрівання, тим інтенсивніший цей процес реакції капілярного потенціалу. Однак при цьому виникає протилежно спрямований процес: у найдрібніших порах порушується рівновага, адже $\mathrm{r}_{\mathrm{a}} \gg \mathrm{r}_{\max }$ стає значно більшим за $\mathrm{r}_{\max }$, що викликає інтенсивну

дифузію газів, що складають бульбашку затиснутого повітря, через рідинні мембрани до грунтової атмосфери. Адже надлишковий газовий тиск в бульбашці визначається різницею радіусів кривизни менісків затиснутого повітря $\left(\mathrm{r}_{\max }\right)$ та на контакті 3 атмосферою $\left(\mathrm{r}_{\mathrm{a}}\right)[8]$. Цей протилежно

спрямований процес зменшує об'єм затиснутого повітря у грунті. Коли швидкість цих протилежних процесів урівнюється, капілярний потенціал досягає свого максимума i, у подальшому, починає знижуватись, особливо 3 настанням охолодження зразка грунту. За охолодження до початкових значень температури, капілярний потенціал продовжує знижуватись, відносно його початкових значень, ще на 10 кПа за рахунок повного розчинення повітря у найдрібніших порах. Після чого триває напівперіод релаксації - повільного відновлення рівноважного стану із встановленням початкових значень капілярного потенціалу. Такий автоколивальний процес у грунті є характерним для будь-якого зовнішнього збурення, в залежності від його швидкості i амплітуди. Зазвичай напівперіод релаксації у четверо-шестеро перевищує напівперіод реакції. Через що, за природної добової циклічності зовнішніх збурень напівперіод релаксації завжди лишається незавершеним. В цьому полягає перманентна термодинамічна нерівноважність грунтового середовища у взаємодії із зовнішніми факторами.

Цей факт вимагає звернення до інструментарію синергетики, ключовим для якої є поняття активного кінетичного середовища. I грунт відповідає його основним вимогам: в ньому наявне розподілене у об'ємі джерело енергії i/або речовини, що багата на енергію; кожний елементарний об’єм знаходиться у стані далекому від термодинамічної рівноваги; зв'язок між сусідніми елементарними об' ємами здійснюється за рахунок процесів переносу [6]. 
Слід зауважити, що у сучасній агрофізиці відсутній елементарний об'єм як організаційний рівень грунтової маси. Однак він $\epsilon$ основоположним для термодинаміки і синергетики, тому слід доповнити організаційну структуру грунту поняттям елементарного об'єму, що поєднує крім твердих дисперсних часток ще й поровий розчин і повітря. Важливим для грунту моментом $\epsilon$ ідентифікація розподіленого джерела енергії у грунті. Стереотипом сучасного грунтознавства є твердження, що ледь не єдиним джерелом енергії у грунті $\epsilon$ органічна речовина. Однак за повільного іiі вивільнення при біохімічному розкладі органіки ця енергія не здатна впливати на динаміку термодинамічного стану грунту, адже кінетична складова енергобалансу грунту у рази перевищує енергоємкість органічної речовини. Кінетична складова енергобалансу грунту визначається рівнем дисипації (перетворення, розсіювання) зовнішнього потоку енергії, переважно сонця.

Субординаиійні гомеостатичні процеси. Приклад такого енерговитратного процесу перетворення теплового імпульсу ми розглянули вище, сутністю якого $\epsilon$ внутрішньопоровий перерозподіл вологи у тривимірній структурі грунтової матриці із тимчасовим зростанням поверхневої енергії грунту за рахунок інтрагетерогенності. Однак затиснення рідинними мембранами повітря у розширеннях порового простору породжує ще цілу низку енерговитратних субординаційних (внутрішніх) процесів. Зокрема зростання газового тиску у бульбашці призводить до дифузії через рідинні мембрани газів, що іiі складають. Зазвичай у грунтовій атмосфері фіксують підвищений вміст діоксиду вуглецю $\left(\mathrm{CO}_{2}\right)$ - до - $3 \%$. I саме цей газ має найвищу розчинність у воді. Дисоціюючи у розчині, він підвищує його кислотність (pH). Тобто бульбашка повітря стає кислотним центром (КЦ) із виникненням відцентрового градієнта кислотності. У свою чергу, підвищення кислотності порушує фазову рівновагу чутливих до цього параметра сполук органічної, органо-мінеральної та мінеральної природи, що зазвичай тяжіють до контактів дисперсних часток, цементуючи їх між собою. Звільнення від цементу може створити унікальні умови для відносного пересування дисперсних часток із збільшенням, або зменшенням об'єму елементарної пори, або макропори. При цьому також йде відцентровий конвективний перерозподіл розчинених цементуючих сполук 3 їхнім випадінням у осад на певній відстані від бульбашки у відповідності 3 градієнтом рН. Тобто у структурі грунтової матриці йде радіальне зонування від КЦ гомологічних рядів сполук чутливих до кислотності порового розчину. Це, в свою чергу, призводить до підвищення міцності цементації дисперсних часток сполуками, що найменш чутливі до кислотності порового розчину у радіально найвіддаленіших областях грунту. I саме ці найбільш зцементовані області стають зародками окремостей, на які розкладається грунт при його обробітках по найменш зцементованих макропорах i ï довкіллі. Таким вбачається вірогідний механізм формування структури грунту за класичного іiі розуміння за циклічного перемивання сполук при взаємодії з циклічними факторами зовнішнього середовища. I саме такого транспортного механізму не вистачало у теоріях гумусоутворення [22] та концепціях формування структури грунту [12]. Слід акцентувати увагу на відцентровій циркуляції 
низькомолекулярних гумусових сполук, розчинність яких суттєво залежить від кислотності розчину, зокрема зниження їх розчинності по мірі зростання лужності розчину [22]. Отже гумусові речовини у зворотно-поступальних рухах, окрім зміцнення цементації віддалених від КЦ областей, забезпечують якісну термодинамічну зборку високомолекулярних гумусових речовин власне гумусу. I це явище може бути інтерпретоване не як хімічний процес, а як термодинамічний процес гумусоутворення i подальшого специфічного оборотного функціонування його у грунтових процесах.

Усі вищезазначені субординаційні процеси є енерговитратними і мають пряме відношення до утворення структури грунту. Саме тому вони підтримують гомеостаз системи грунту через відтворення структурної організації та основних властивостей (водно-фізичних, міцнісних тощо). 3 іншого боку, гомеостаз контролюється рівнем дисипації в ньому зовнішнього потоку енергії. Тобто певний рівень дисипації зовнішнього потоку енергії у грунті забезпечується субординаційними процесами певної інтенсивності. У загальному випадку інтенсивність гомеостатичних процесів залежить від: конструкції термодинамічної системи грунту, тобто від структури його порового простору; наявності вологи, як робочого тіла, від кількості якої залежить ККД системи; інтенсивності зовнішніх збурень (кліматичних чинників). Саме тому поняття гомеостазу грунту $\epsilon$ незамінним при прогнозуванні еволюційних змін властивостей грунтів за сучасних швидких глобальних кліматичних змін. Яскравим прикладом системної реакції грунтового середовища на зміну гомеостазу грунту $є$ утворення у профілі орних грунтів так званої плужної підошви. Системним чинником іiі утворення $\epsilon$ зниження гомеостазу у підорному горизонті за рахунок підвищення гомеостазу в орному шарі. В даному випадку контакт розпушеного орного і підорного горизонтів відіграє роль радіального ландшафтно-геохімічного бар'єра (ЛГБ) [14], який має першочергово енергетичну природу. Найвірогідніше структурнофункціональна організація грунту вищих порядків - пошарова і плановопросторова, теж має характер енергетичного обміну, що може бути розшифрований 3 використанням поняття гомеостазу, як визначальною складовою енергоспоживання грунтом зовнішнього потоку енергії.

Отже, підводячи підсумок результатів проведених досліджень, можемо констатувати, що застосування термодинамічних методів до вивчення грунтової організації дозволяє стверджувати, що структуру грунту на кількісному рівні характеризує структура його порового простору. На основі лабораторних гідрофізичних досліджень грунту непорушеної структури 3 використанням явища гістерезису розроблений спосіб визначення структури порового простору грунту, тобто одержання диференційної кривої розподілу сумарного об' єму порового простору за радіусами [14,19]. 3 використанням цього способу експериментально встановлено закономірності епігенетичних змін структури порового простору для різних типів грунтів у просторі і часі, що узгоджуються 3 поняттям їх гомеостазу та дією антропогенних чинників. Деталізовано субординаційні процеси, що розвиваються у грунті під дією зовнішніх збурень термодинамічного характеру. Встановлено надзвичайно важливу роль 
макропор, які стають у мікроградієнтній структурі грунту центрами термодинамічної нерівноважності (ЦТН), своєрідним рушієм порового розчину, що відіграє роль транспортного механізму розчиненої речовини, кислотними центрами (КЦ), що забезпечують фазові переходи речовини, а також центрами екотонів для грунтової мікробіоти. Особливої уваги заслуговує також підвищений вміст діоксиду вуглецю $\left(\mathrm{CO}_{2}\right)$ у грунтовій атмосфері, що контролює кислотність i фазові переходи у структурі грунтової матриці. Загалом одержані результати дозволяють наповнити конкретикою «концепт синергетичної моделі грунтів», що був сформульований у роботі [5]. Отримані нові знання про будову i функціональні параметри грунту та розроблений інструментарій лабораторних термодинамічних досліджень, що дозволяють характеризувати структуру порового простору, визначати пороговий розмір структурної макропористості та отримувати більшість водно-фізичних констант грунту [19].

\section{Висновки.}

Альтернативний погляд на грунт як термодинамічну систему дозволив встановити характер його термодинамічної взаємодії з факторами зовнішнього середовища. В основі такої взаємодії покладено перетворення (дисипацію) потоку зовнішньої енергії сонця у локальних субординаційних процесах перерозподілу речовини 3 фазовими переходами, результатом яких $\epsilon$ просторово неоднорідна цементація дисперсних часток тривимірної грунтової матриці.

3 позиції синергетики грунт являє собою мікроградієнтну дисипативну систему потокового типу, в якій особлива роль належить макропорам, що $\epsilon$ центрами термодинамічної нерівноважності (енергетичними центрами), кислотними центрами та центрами екотонів для грунтової мікробіоти.

Поняття гомеостазу грунту розглядається як динамічна рівновага структурної організації, що визначена рівнем дисипації зовнішнього енергетичного потоку у локальних субординаційних процесах. Порушення структурної організації або зміна зовнішнього потоку енергії (клімату) порушують гомеостаз грунту 3 можливими негативними наслідками i еволюцією властивостей. Прогресивним напрямком розвитку грунтоутворення та відповідного рівня гомеостазу є максимальне використання зовнішнього потоку енергії з розвитком структурної макропористості, стійкої до зовнішніх факторів. Гомеостаз грунту має відношення до основних функцій грунту продуктивної, екологічної по збереженню і накопиченню складових живлення та інформаційної по накопиченню у грунті інформації та іiі трансформації і передачі трофічними ланцюгами.

\section{Література:}

1. Антропогенная и естественная эволюция почв и почвенного покрова. Материалы (тезисы) Всесоюзного совещания (г. Москва, 10-12 января 1989 г.). Москва: Пущино, 1989. 340 с.

2. Волобуев В.Р. Экология почв (очерки). Баку: АН Азерб. ССР, 1963. 260 c. 
3. Волобуев В.Р., Пономарев Д.Г., Микаилов Ф.Д. Связь между термодинамическими функциями почв, их менерологическим составом и фильтрационной способностью // Почвоведение. 1980. №3. С.102-105.

4. Деградація грунтів у світі, досвід ії попередження і подолання. Мєдвєдєв В.В., Пліско І.В., Накісько С.Г., Тітенко Г.В. Харків: Стильна типографія, 2018. $168 \mathrm{c}$.

5. Долгинова В.А., Рыбальский Н.Н. Синергетический метод познания почвы // Использование и охрана природных ресурсов в России. 2019. № 4. С. $22-26$.

6. Дружинин Д.Л., Ванярхо В.Г. Синергетика и методология системных исследований. Системные исследования. Методологические проблемы. Ежегодник. Москва: Наука, 1989. С.283-303.

7. ДСТУ ISO 11274:2001. Якість грунту. Визначання водоутримувальної характеристики. Лабораторні методи (ISO 11274:1998, IDT). [Чинний від 200307-01]. Вид. офіц. Київ : Держспоживстандарти України, 2003. 37 с. (Національний стандарт України).

8. Коломієць С.С. Екологічна характеристика грунту // Вісник аграрної науки. Київ, 1999. №12. С.9-13.

9. Корнев В.Г. Всасывающая сила почвы и принципы системы автоматического орошения почвы. Москва: Издание ГИСХМ, 1925. 30 с.

10. Лыков А.В. Теория сушки. Москва: Госенергоиздат, 1950. 416 с.

11. Память почв: Почва как память биосферно-геосферно-антропогенных взаимодействий ; ред. В.О. Таргульян, С.В. Горячкин. Москва: ЛКИ, 2008. $692 \mathrm{c.}$

12. Панасенко О.С. Гумус структурних агрегатів чорноземів типових природних і агрогенних екосистем: монографія; за ред. В.В. Дегтярьова. Харків: Майдан, 2015. 192 с.

13. Перельман А.И. Биокосные системы Земли. Москва: Наука, 1977. 160 с.

14. Почвоведение. Учеб. для ун-тов. В 2 ч. /Под ред. В.А. Ковды, Б.Г. Розанова. Ч.1. Почва и почвообразование // Г.Д. Белицына, В.Д. Васильевская, Л.А. Гришина и др. Москва: Высшая школа, 1988. 400 с.

15. Пригожин И.Р. Время, структура и флуктуация : Нобелевская лекция по химии 1977 года. Успехи физических наук, 1980. т.131. Вып.2. С185-207.

16. Реймерс Н.Ф. Природопользование. Словарь-справочник. Москва: Мысль, 1990.650 с.

17. Роде А. А. Основы учения о почвенной влаге. т. 1. Ленинград: Гидрометеоиздат, 1965. С. 663.

18. Роде А.А. О «почве-памяти», «почве-моменте» и двуединстве почвы // Почвоведение. 1980. № 3. С. 127-131.

19. Ромащенко M.I., Коломієць С.С., Білоброва А.С. Система лабораторного діагностування водно-фізичних властивостей грунтів // Меліорація і водне господарство : Міжвід. темат. наук. зб. Київ, 2019. №2. С. 199-208. DOI: 10.31073/mivg201902-193.

20. Саати Т., Кернс К. Аналитическое планирование. Организация систем : пер. с англ. - М: Радио и связь, 1991. 224 с. 
21. Словник-довідник з агроекології ; за ред. О.І. Фурдичка. Київ: Основа, 2007. $272 \mathrm{c}$.

22. Федотов Г.Н., Шоба С.А. Существующие представления о возможных путях формирования гумусовых веществ в почвах // Почвоведение. 2013. № 12. C 1523-1529.
23. Хакен
Г. Синергетика:
иерархия
неустойчивостей
B самоорганизующихся системах и устройствах. Москва: Мир, 1985. 419 с.

24. Шевченко О.Л., Бублясь В.М., Коломієць С.С. Основи перенесення вологи в зоні аерації: навчальний посібник. Київ: Видавничо-поліграфічний центр «Київський університет», 2014. 270 с.

Abstract. The purpose of the publication is to reveal the internal processes carried out in the soil in interaction with cyclically changing external climatic factors and to prepare the concept of soil homeostasis. Methods of synergetic and thermodynamic, experimental researches are used. The occurrence of the self-oscillating process of capillary potential dynamics under the influence of temperature, atmospheric pressure, or humidity has been experimentally established. Basically on this phenomenon is the clamping by liquid membranes in the expansion of the pore space of air, which response to the variability of external thermodynamic parameters by changing its volume and gas pressure, like a membrane pump. This generates a number of centrifugal local processes in the compressed air environment: moisture redistribution with substance convective transport, $p H$ change, violation of phase imbalance, selection of compounds which acidity sensitive, zoning in space, and their postponement. This provides uneven cementation of dispersed particles and determines the germs of the individuals into which the soil decomposes during cultivation. The intensity of subordination processes determines the level of transformation (dissipate) of the external flow of energy (sun). In the general case, this intensity is determined by the system construction (structure of pore space); the presence of moisture as a working fluid, the content of which depends on the coefficient of performance of the soil thermodynamic system and the intensity of fluctuations of external thermodynamic parameters. From the standpoint of synergetic, the soil is defined as a microgradient dissipative system of the flow type. Soil homeostasis is defined as a set of subordinate energy consumption processes that determine a certain level of transformation (dissipation) of solar energy flow and ensure the reproduction of structural organization and basic properties, and also realize the productive and ecological functions of soil. The concept of soil homeostasis is indispensable for assessing the evolutionary changes in their properties in modern global climate change.

Keywords: soil, thermodynamic system, synergetic, heterogeneity, homeostatic processes, air compression, the structure of pore space, soil homeostasis

Науковий керівник: д.т.н., проф., академік НААН Ромащенко М.I.

Стаття відправлена: 29.12.2020 p.

(C) Коломієць С.С., Білоброва А.С. 